\title{
Combination of trichosanthes cucumerina L. compounds: an analysis for novel effects of anticancer cell activites as probes for pharmacological studies
}

Md Ariful Haque Mollik ${ }^{1,2}$

From Society for Immunotherapy of Cancer 28th Annual Meeting

National Harbor, MD, USA. 8-10 November 2013

Prostate cancer is a hormone-dependent cancer and its proliferation is stimulated by endogenous steroid hormones. Aromatase (CYP19) and 5 $\alpha$-reductase (SRD5A) are the key enzymes that synthesize these hormones. Aromatase converts androgens to estrogens and $5 \alpha$-reductase converts testosterone to dihydrotestosterone. Natural compounds present in the Trichosanthes cucumerina $\mathrm{L}$. delay prostate cancer progression. These compounds may act as inhibitors of steroidogenesis. Trichosanthes cucumerina L. compounds (punicic-, quinic-, gallic-, trans-vaccenic-, and cis-vaccenic-, pelargonidin-, cyanidin-, malvidin-, and delphinidin chloride, epicatechin gallate, epicatechin, kaempferol, and epigallocatechin) were tested in vitro in a hormone-dependent prostate cancer ( $\mathrm{LNCaP}$ cells) and steroidogenesis (human adrenocortical H295R cells) model. Cells (5000 cells $/ \mathrm{ml}$ ) in 96 well culture plates were exposed to various concentrations of Trichosanthes cucumerina L. compounds for 6 days with a fresh reexposure after 48 hours. For cytotoxic effects, H295R were exposed once to Trichosanthes cucumerina L. compounds for 24 hours. Cytotoxicity and antiproliferative effects were measured with WST-1 reduction assay. Catalytic activity of CYP19 was determined in H295R cells by tritiated water-release assay. Punicic acid had an antiproliferative effect in LNCaP cells reducing cell growth by 78,88 , and $91 \%$ at 30,45 , and $100 \mu \mathrm{M}$ respectively. Kaempferol reduced proliferation by 30,48 , and $69 \%$ at 15,30 , and $100 \mu \mathrm{M}$ respectively. Punicic acid was not cytotoxic in H295R cells, and at $30 \mu \mathrm{M}$, decreased aromatase activity by $75 \%$ compared to control. CYP19 was not

${ }^{1}$ Biological Sciences, Peoples Integrated Alliance, Bogra Sadar, Bangladesh Full list of author information is available at the end of the article express in LNCaP cells. Preliminary consequences show that various natural compounds found in the Trichosanthes cucumerina L. have an antiproliferative effects in LNCaP cells and punicic acid acts as an aromatase inhibitor in H295R cells.

\section{Authors' details}

${ }^{1}$ Biological Sciences, Peoples Integrated Alliance, Bogra Sadar, Bangladesh. ${ }^{2}$ Research and Development, Prescience Trust Funds, Phoenixville, PA, USA.

Published: 7 November 2013

doi:10.1186/2051-1426-1-S1-P134

Cite this article as: Mollik: Combination of trichosanthes cucumerina L. compounds: an analysis for novel effects of anticancer cell activites as probes for pharmacological studies. Journal for Immunotherapy of Cancer 2013 1(Suppl 1):P134.

Submit your next manuscript to BioMed Central and take full advantage of:

- Convenient online submission

- Thorough peer review

- No space constraints or color figure charges

- Immediate publication on acceptance

- Inclusion in PubMed, CAS, Scopus and Google Scholar

- Research which is freely available for redistribution 